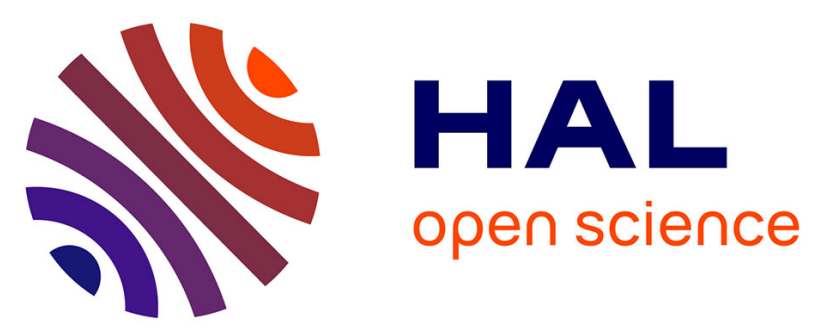

\title{
The unusual action of essential oil component, menthol, in potentiating the effect of the carbamate insecticide, bendiocarb
}

Milena Jankowska, Bruno Lapied, Waldemar Jankowski, Maria Stankiewicz

\section{- To cite this version:}

Milena Jankowska, Bruno Lapied, Waldemar Jankowski, Maria Stankiewicz. The unusual action of essential oil component, menthol, in potentiating the effect of the carbamate insecticide, bendiocarb. Pesticide Biochemistry and Physiology, 2019, 158, pp.101-111. 10.1016/j.pestbp.2019.04.013 . hal02559640

\author{
HAL Id: hal-02559640 \\ https://univ-angers.hal.science/hal-02559640
}

Submitted on 8 Dec 2021

HAL is a multi-disciplinary open access archive for the deposit and dissemination of scientific research documents, whether they are published or not. The documents may come from teaching and research institutions in France or abroad, or from public or private research centers.
L'archive ouverte pluridisciplinaire HAL, est destinée au dépôt et à la diffusion de documents scientifiques de niveau recherche, publiés ou non, émanant des établissements d'enseignement et de recherche français ou étrangers, des laboratoires publics ou privés. 


\title{
The unusual action of essential oil component, menthol, in potentiating the effect of the carbamate insecticide, bendiocarb
}

\author{
Milena Jankowska $^{\mathrm{a}, *}$, Bruno Lapied ${ }^{\mathrm{b}}$, Waldemar Jankowski ${ }^{\mathrm{a}}$, Maria Stankiewicz ${ }^{\mathrm{a}}$ \\ ${ }^{\text {a }}$ Faculty of Biology and Environmental Protection, Nicolaus Copernicus University, Toruń, Poland \\ ${ }^{\mathrm{b}}$ Laboratoire SiFCIR UPRES EA 2647/USC INRA 1330, Université d'Angers, UFR Sciences, Angers, France
}

\section{A R T I C L E I N F O}

\section{Keywords:}

Carbamate

Menthol

Acetylcholinesterase

Cockroach

\begin{abstract}
A B S T R A C T
Standard chemical insecticides present mainly neurotoxic effects and are becoming less and less effective due to insects developing resistance to them. One of the innovative strategies to control insects pests is to find a way to increase the sensitivity of the target sites in the insect nervous system to the applied insecticides. In the presented research, we proposed menthol, a component of essential oils, as a factor increasing the effectiveness of bendiocarb, a carbamate insecticide. The aim of our study was to evaluate the potentiation of the bendiocarb effect by menthol. In toxicity tests performed on Periplaneta americana, menthol $(0.1 \mu \mathrm{M})$ accelerated the lethal effect of bendiocarb, primarily in its low concentrations (lower than $0.05 \mathrm{mM}$ ). In the presence of menthol ( 1 and $0.1 \mu \mathrm{M})$, the ability of insects to turn back from its dorsal to the normal ventral side was significantly lower than with bendiocarb $(1 \mu \mathrm{M})$ alone. We also evaluated the effectiveness of chemicals on the activity of the ventral nerve cord of the cockroach. In this preparation, bendiocarb $(1 \mu \mathrm{M}$ and higher concentrations) caused an irregular, spontaneous bursts of action potentials. The total nerve activity (including the response to stimulation and spontaneous firing) was much higher when bendiocarb was applied in the presence of menthol $(1 \mu \mathrm{M})$. The effect of menthol was similar to the octopamine effect and was abolished by phentolamine, the octopamine receptor antagonist. Our results clearly indicated a strengthening effect of menthol on bendiocarb effectiveness; potentiation occurred through octopamine receptors activation.
\end{abstract}

\section{Introduction}

Insects are the most populous group in the animal kingdom and form a very important component of the ecosystem. However, some insects are harmful to human interest, transferring dangerous pathogens as well as causing damages to crops and stored food. Since the 1940 's, people have fought against insect pests using chemical insecticides (Casida and Durkin, 2013). Although they are effective, they can have several undesirable consequences, such as negative impacts on human health (Ding et al., 2015; Schinasi et al., 2015) and toxicity to non-target animals (Antwi and Reddy, 2015; Pisa et al., 2015). Moreover, they have become less and less effective due to insects developing some resistance to insecticides (Buckingham et al., 2017; Dong, 2007; ffrench-Constant et al., 2004; Thara et al., 2017; Perry et al., 2011).

One of the latest, innovative strategies to control insect pest is the co-application of chemical insecticides with activators of membrane metabotropic receptors such as cholinergic muscarinic receptors (Abd-
Ella et al., 2015). The activation of intracellular pathways leads to an increase in intracellular $\mathrm{Ca}^{2+}$ concentration and the calcium-dependent phosphorylation/dephosphorylation of membrane functional proteins that modify their sensitivity to ligands (Apaire-Marchais et al., 2016; Lavialle-Defaix et al., 2010). These phenomena are considered important cellular mechanisms that are to be used to increase the sensitivity of insects to insecticides (Lapied et al., 2009; Raymond et al., 2017).

Octopamine is a vital regulatory biogenic amine in invertebrates and acts through metabotropic octopamine G-protein-coupled receptors (Beggs et al., 2011; Evans and Maqueira, 2005). It has been demonstrated that the activation of the octopamine receptors lead to the modification of proteins that can serve as targets for chemical insecticides (Leyton et al., 2014; Reale et al., 1986; Vehovszky et al., 2004, 2005). In experiments performed on mosquitoes, positive synergistic effects have been demonstrated between the activators of the octopamine receptors (formamidines) and different insecticide groups

\footnotetext{
Abbreviations: ACh, acetylcholine; AChE, acetylcholinesterase; cAMP, 3',5'-cyclic adenosine monophosphate; ED, effective dose; EO, essential oil; GABA, gammaaminobutyric acid; nAChR, acetylcholine nicotinic receptor; PKC, protein kinase C; TAG, terminal abdominal ganglion

* Corresponding author at: Faculty of Biology and Environmental Protection, Nicolaus Copernicus University, Torun, Poland. ul. Lwowska 1, 87-100 Toruń, Poland.

E-mail address: mjank@umk.pl (M. Jankowska).
} 
(pyrethroids, neonicotinoids, organophosphorus and insect growth regulators) (Ahmed and Matsumura, 2012; Ahmed and Vogel, 2015, 2016).

The octopamine receptors are one of the targets of the $\mathrm{EO}^{1}$ components (Enan, 2001; Jankowska et al., 2017; Kostyukovsky et al., 2002). They cause a decrease in the binding of octopamine to its receptors (Enan, 2001). The EO components induce an increase in the cAMP $^{2}$ level in the epidermal tissue of the cotton bollworm which is inhibited by phentolamine (Kostyukovsky et al., 2002). These EO components mimic the octopamine effect on the firing rate in the nerve cord of the cockroach (Price and Berry, 2006). They also increase $\mathrm{Ca}^{2+}$ concentrations in HEK-293 cells expressing octopamine receptors from the cockroach and the fruit fly (Enan, 2005).

Essential oils and their components have become objects of increasing interest in integrative pest management. They exhibit an insecticidal and repellent activity and are increasingly being proposed as an alternative to synthetic insecticides (Pavela, 2016; Pavela and Benelli, 2016). However, they are usually less effective and thus cannot replace the chemicals alone in insect control. Different sites of action of essential oils in the insect nervous system are described: the inhibition of acetylcholinesterase, the positive modulation of the $\mathrm{GABA}^{3}$ receptors, and as stated above, the activation of the octopamine receptors (Enan, 2001; Jankowska et al., 2017; Park et al., 2016; Tong and Coats, 2010). Menthol has been shown to act as a positive modulator of GABA receptors in mammals as well as an inhibitor of Sitophilus oryzae $\mathrm{AChE}^{4}$ (Lee et al., 2001; Hall et al., 2004).

In our research, we hypothesise that menthol, acting through octopamine receptors, will enhance the efficiency of the carbamate insecticide - bendiocarb. Carbamates inhibit acetylcholinesterase enzyme in the insect nervous system (Casida and Durkin, 2013) and their efficiency has already been shown to be changed by the activation of the metabotropic muscarinic receptors (Abd-Ella et al., 2015).

In electrophysiological experiments we have shown the high similarity in the action of menthol and octopamine which indicates that menthol, like other active constituents of essential oils (Kostyukovsky et al., 2002), activates the octopaminergic receptors. In toxicity tests on cockroach, as well as in experiments on its nervous system, we demonstrated for the first time the potentiating effect of menthol on the efficacy of a carbamate insecticide.

\section{Methods}

\subsection{Insects and reagents}

\subsubsection{Insects}

Experiments were performed on adult male cockroaches (Periplaneta americana); obtained from own breeding. We always use only males because they have a more stable physiology than females (no changes related to reproduction). In addition, dissection of the nervous system of male cockroaches for electrophysiological experiments is easier. The animals were kept at $29^{\circ} \mathrm{C}$ and fed oat flakes and cat chow with access to water ad libitum. The insects were moved from breeding cages in plastic boxes to the laboratory $24 \mathrm{~h}$ before the experiments to allow them to adapt to the new conditions.

\subsubsection{Reagents}

Bendiocarb insecticide was dissolved in ethanol to the concentration of $0.1 \mathrm{M}$ since its solubility in water is low. Serial dilutions of $1 \mathrm{mM}$, and subsequently $500,200,100,50,10,1,0.1 \mu \mathrm{M}$ were then made in water (for toxicity tests) or in physiological saline (for electrophysiological

\footnotetext{
${ }^{1}$ EO - essential oil.

${ }^{2}$ cAMP - 3',5'-cyclic adenosine monophosphate.

${ }^{3}$ GABA - gamma-aminobutyric acid.

${ }^{4}$ AChE - acetylcholinesterase.
}

experiments). Physiological saline contained in mM: $\mathrm{NaCl}-210, \mathrm{KCl}-$ 3.1, $\mathrm{CaCl}_{2}-5, \mathrm{MgCl}_{2}-5.4$, and Hepes -5 . The $\mathrm{pH}=7.2$ was adjusted with $\mathrm{NaOH}$. Menthol was dissolved in ethanol to the concentration of $0.1 \mathrm{M}$, then it was diluted in water or in physiological saline to the concentration of $1 \mu \mathrm{M}$ and $0.1 \mu \mathrm{M}$. Bendiocarb (Pestanal, analytical standard), DL-octopamine hydrochloride, Phentolamine hydrochloride ( $\geq 98.0 \%$ (TLC), ( \pm )-Menthol (racemic $\geq 98.0 \%$ ), and Hepes were purchased from Sigma Aldrich. The physiological saline components $\mathrm{NaCl}, \mathrm{KCl}, \mathrm{MgCl}_{2}, \mathrm{CaCl}_{2}$ ) - were obtained from Polskie Odczynniki Chemiczne. SA. Poland.

\subsection{Toxicity tests}

\subsubsection{Assessment of motor skills}

Bendiocarb as an acetylcholinesterase inhibitor causes hyperactivity and then paralysis of insects. In our toxicity tests, we estimated the level of cockroach paralysis induced by bendiocarb, menthol and bendiocarb and menthol applied together. Each cockroach was placed on the dorsal side (on cork arena) and its ability to turn back to its normal position was estimated by measuring the time necessary to return to the ventral side. We assumed that the more affected insects would need more time to turn back.

A group of five insects were placed in a 0.6651 non-absorbing, glass chamber ( $11 \mathrm{~cm}$ diameter, $7 \mathrm{~cm}$ height) and exposed to chemicals for $1 \mathrm{~h} .1 \mathrm{ml}$ of menthol (in the concentrations of $1 \mu \mathrm{M}$ and $0.1 \mu \mathrm{M}$ ) was administered into a filter paper, then the paper was placed directly under the chamber lid. The volatile fraction of terpenoid is heavier than air so its vapor quickly reached the insects at the bottom of the chamber. $0.5 \mathrm{ml}$ of bendiocarb - (in the concentrations of $0.1 \mathrm{mM}$ and $1 \mu \mathrm{M})$ was dispensed in a form of spray with a glass atomizer directly into the insects in the glass chamber. The menthol and bendiocarb were applied at the same time. After $1 \mathrm{~h}$ of exposure, the insects were tested for motor skills. The tests were recorded with a video-camera which allowed for precise evaluation of the time necessary for the insects to turn back to their normal position with a degree of accuracy of $0.001 \mathrm{~s}$. All experiments were repeated 3 times with $n=15$ for all mean values.

\subsubsection{Knockdown tests}

To evaluate the efficiency of bendiocarb and the potentiation of its effect by menthol, we performed tests in which knockdown of the cockroaches was observed. Six adult male insects were placed together in a 1.71 non-absorbing, cubic glass chamber $(12 \mathrm{~cm} \times 12 \mathrm{~cm} \times 12 \mathrm{~cm})$ for $12 \mathrm{~h}$. $1 \mathrm{ml}$ of menthol (in the concentration of $0.1 \mu \mathrm{M}$ ) was applied into a filter paper. Similar to previous test, the paper was placed directly under the chamber lid. $1 \mathrm{ml}$ of bendiocarb (in the concentrations of $1,0.5,0.2,0.1,0.05,0.01 \mathrm{mM}$ ) was dispensed in a spray form directly into the insects in the glass chamber using a glass atomizer. At intervals of one hour, the number of the paralyzed insects was noted repeatedly. An insect was considered knocked down when it laid upside down without moving. The experiment was replicated 5 times, hence the total number of insects in each variant and concentration was 30 .

Statistical analysis was performed using R software (R Development Core Team, 2011). Since some data did not have a normal distribution, we used the Kruskal-Wallis test for equal median and Mann-Whitney post-hoc tests to compare groups of data using 'FSA' package (Ogle, 2018). Dose-response curves were computed using 'drc', 'sandwich' and 'Imtest' packages (Ritz et al., 2015; Zeileis, 2004; Zeileis and Hothorn, 2002). The knockdown doses were calculated using cumulative Behrens method (Wilbrandt, 1952).

\subsection{Electrophysiological tests}

The efficiency of bendiocarb, menthol and bendiocarb combined with menthol on the cockroach nervous system was tested in vitro at the first part of the insect escape system. The preparation contained the 
cerci, the cercal nerves, $\mathrm{TAG}^{5}$ and the connective nerves with the ganglia from the abdomen. The cercal nerve is connected with the giant and other interneurons by the cholinergic synapses located in the TAG. Recordings of the bioelectrical activity were carried out from the postsynaptic part - the connective nerve close to the TAG.

The preparation was placed in a Petri dish and systematically irrigated with physiological saline to ensure the hydration of the cercal and connective nerves. The cercal appendages were not irrigated seeing that the mechanoreceptors that cover the cercus should be dry to react correctly to stimuli. An extracellular recording electrode (Alpha Omega Engineering LTD, Israel) was placed on the connective nerves while a non-polarized reference electrode was placed in the physiological saline nearby. The electrodes were connected with a preamplifier and then with a compensatory amplifier which allowed to record the spontaneous and induced activity of the nerve cord. The bioelectric signals were observed on an oscilloscope and intercepted by a modified software, Hameg (Germany).

One cercus was stimulated by delicate air puffs applied with $0.75 \mathrm{~Hz}$ frequency emitted by a mechanostimulator. A stimulus was evoked by a movement of a loudspeaker membrane, actuated by an impulse generator. The response to the stimulation (registered during $100 \mathrm{~ms}$ per one entry) and the total activity (registered during 10 s per one entry) of the connective nerve were recorded. Each entry consisted of one thousand bars, each one being a sum of compound action potentials (the height of the bar indicated the amount of the compound action potentials). As a result, in the case of recording the response to the stimulation one bar referred to the sum of the action potentials collected in $0.1 \mathrm{~ms}$ and in the case of the total activity, in $10 \mathrm{~ms}$ (Fig. 2A).

In all the experiments, the same patterns of the electrophysiological recordings were used. Each recording of the response to the stimulation consisted of (1) resting (spontaneous), usually very low activity, (2) response to a mechanical stimulation of the cercus, usually well-defined through time and (3) again resting activity mostly very low. The recordings of the total nerve activity were performed simultaneously. Each record (Fig. 2A) consisted of spontaneous nerve activity and reactions to stimulation visible in control as a single high peak of firing. The size of the total activity was determined mainly by the level of spontaneous activity (the participation of responses in the total activity did not exceed 10\%). Two kinds of experiments were performed: (1) we logged 70 min of recordings in control conditions; (2) first we logged 10 min of control recordings, named "basic activity", using only physiological saline. The preparations were then exposed to the tested compound(s) and observed for one hour (if it was variant with menthol applied with bendiocarb, the essential oil was administrated $5 \mathrm{~min}$ before carbamate).

The magnitude of the response to the stimulation was calculated, using the Hameg software as the "response surface". This means that the specified response time was multiplied by all the bioelectric signals that appeared at that time. The duration of the response was stable in the given experiment and the time frame containing the response chosen at the beginning was applied to all the records in the experiment. In the case of the total connective nerve activity, the time of the entire record (10 s) was analyzed.

The collected data was further analyzed using $R$ software ( $R$ Development Core Team, 2011). The results were expressed as mean values $\pm \mathrm{SE}$ and the comparison of several data groups was made using Kruskal-Wallis test. The differences between groups were tested by Mann-Whitney post-hoc tests. The dose-response curves were established using 'drc', 'sandwich' and 'lmtest' (Ritz et al., 2015; Zeileis, 2004; Zeileis and Hothorn, 2002).

\footnotetext{
${ }^{5}$ TAG - terminal abdominal ganglion.
}

\section{Results}

\subsection{Influence of menthol on the efficiency of bendiocarb in the toxicity tests}

\subsubsection{Assessment of motor skills}

Motor skills were expressed as the time necessary for the insects to turn back from their dorsal (upside down) to their ventral (normal) position. In control conditions, all insects returned from the dorsal to the normal position within $0.7 \pm 0.1 \mathrm{~s}$. The application of menthol in the concentration of $1 \mu \mathrm{M}$ did not change significantly the ability of the insects to turn back (Fig. 1A). However, a lower concentration of menthol $(0.1 \mu \mathrm{M})$ extended the time needed for the insects to return to the normal position up to $10 \pm 4.3 \mathrm{~s}(p=.0002)$ (Fig. 1A) surprisingly. Menthol in the concentration of $0.01 \mu \mathrm{M}$ was less effective and caused an increase in time to $7.1 \pm 3.3 \mathrm{~s}(p=.03)$. Bendiocarb tested alone at the concentration of $1 \mu \mathrm{M}$ caused only a slight extension of the time necessary for the insects to return to the normal position At the concentration of $0.1 \mathrm{mM}$ bendiocarb extended this time to $6.4 \pm 3.1 \mathrm{~s}$ $(p=.02$ ) (Fig. 1A). Bendiocarb at concentrations lower than $1 \mu \mathrm{M}$ did not cause any effect (Supplementary Fig. 1A). The lowest concentration of bendiocarb $(1 \mu \mathrm{M})$ at which any effect was observed was chosen to assess the effect of menthol on the efficacy of bendiocarb. This was combined with two concentrations of menthol $(0.1$ and $1 \mu \mathrm{M})$.

The use of $1 \mu \mathrm{M}$ bendiocarb in combination with $0.1 \mu \mathrm{M}$ menthol caused an increase in the time necessary for the insects to return to the normal position to $18.9 \pm 7.24 \mathrm{~s}(p=.0037)$ This represented a 14fold increase in recovery time compared to when bendiocarb was applied alone (Fig. 1A). As a result, the effect of the mixed substances on the test insects was $56 \%$ higher than the sum of their individual effects. A corresponding effect was observed when $1 \mu \mathrm{M}$ bendiocarb was applied together with $1 \mu \mathrm{M}$ of menthol. The effect was 8 times higher than in the case of bendiocarb acting alone $(p=.0292)$. This potentiating effect was $270 \%$ higher than the sum of the effects of bendiocarb and menthol applied in the same concentrations separately. Obtained results clearly indicated that menthol potentiated strongly the efficiency of bendiocarb.

\subsubsection{Knockdown tests}

In the previous series of experiments, menthol at the concentration of $0.1 \mu \mathrm{M}$ produced a more significant effect on the motor skills of the insects. Knockdown tests were carried out using this concentration which alone never induced any visible signs of paralysis in the insects. The cockroaches were treated with bendiocarb separately and also in conjunction with menthol in concentrations previously indicated in the Methods section. The time from application to knockdown was then measured. Bendiocarb at the concentration of $1 \mathrm{mM}$ when applied, almost immediately caused paralysis and within an hour produced paralysis in $100 \%$ of the insects. Lower concentrations of bendiocarb took longer to cause a knockdown- $0.05 \mathrm{mM}$ of bendiocarb took $5 \mathrm{~h}$ to cause the first signs of paralysis while it took $7 \mathrm{~h}$ to initiate knockdown at the concentration of $0.01 \mathrm{mM}$ (Fig. 1B). At the concentration of $0.05 \mathrm{mM}$, bendiocarb applied in conjunction with menthol induced the first paralysis after $2 \mathrm{~h}$. However, it took $6 \mathrm{~h}$ for $0.01 \mathrm{mM}$ of bendiocarb applied with menthol to initiate paralysis. The development of the knockdown state was much faster when bendiocarb was used together with menthol. For example, while $7 \%$ of the insects were paralyzed after $5 \mathrm{~h}$ of exposure to $0.05 \mathrm{mM}$ of bendiocarb alone, a treatment with a combination of bendiocarb and menthol caused $43 \%$ to be paralyzed in the same time frame and concentration. Likewise, $8 \mathrm{~h}$ of exposure to $0.01 \mathrm{mM}$ bendiocarb alone and to a combined treatment of bendiocarb and menthol resulted in $12.5 \%$ and $46 \%$ paralyzed insects respectively (Fig. 1B). The co-application of menthol with bendiocarb at high concentrations $(0.5$ and $1 \mathrm{mM})$ did not result in any significant increase in the bendiocarb efficiency. Probably, the effect caused by bendiocarb alone was too fast and there was no time for the menthol to take effect. The cumulative dose-response curves for the knockdown effect for 
A

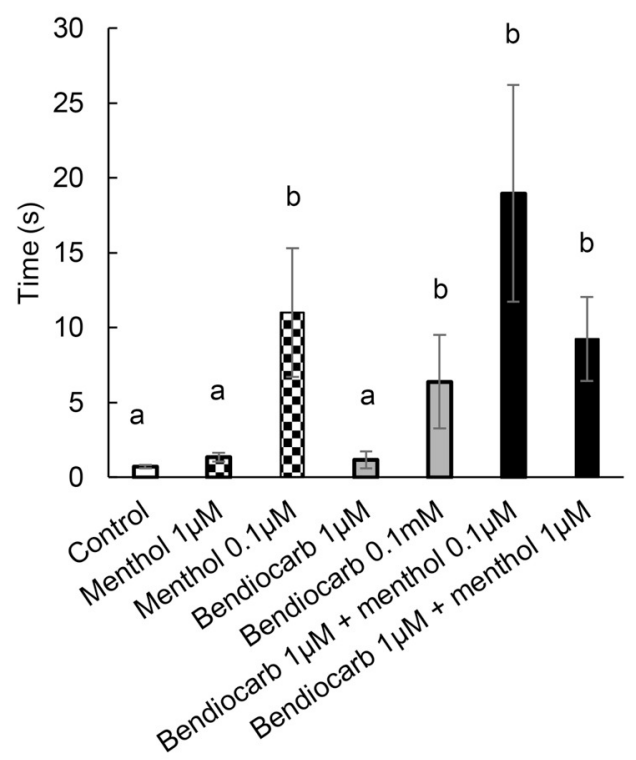

C

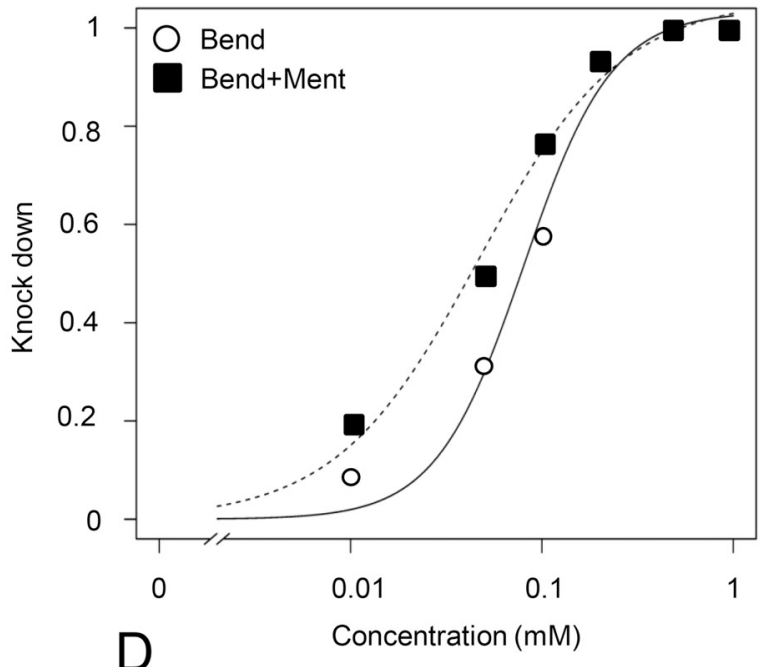

\begin{tabular}{lll} 
& Bendiocarb & Bendiocarb + Menthol \\
\hline $\mathrm{ED}_{5}$ & $16.97 \mu \mathrm{M}$ & $3.74 \mu \mathrm{M}$ \\
$\mathrm{ED}_{10}$ & $25.2 \mu \mathrm{M}$ & $7.1 \mu \mathrm{M}$ \\
$\mathrm{ED}_{50}$ & $80.47 \mu \mathrm{M}$ & $46.79 \mu \mathrm{M}$
\end{tabular}

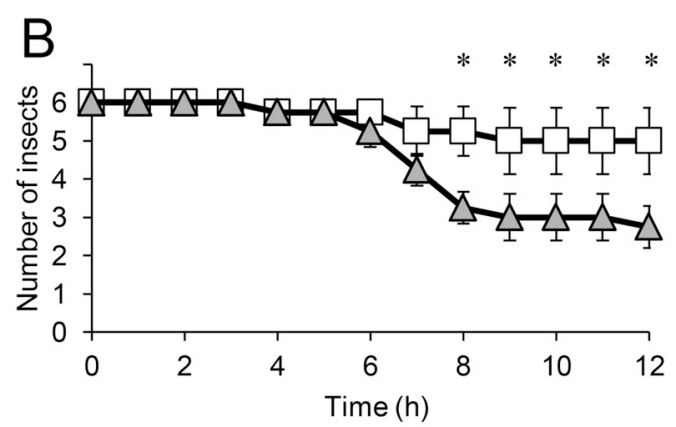

Bend $0.01 \mathrm{mM}$

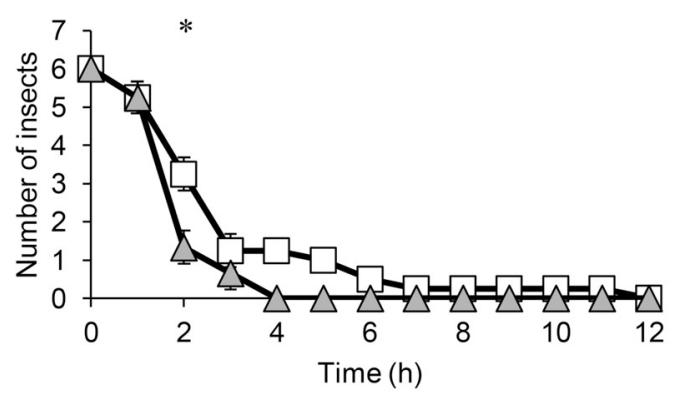

Bend $0.5 \mathrm{mM}$

Bend $0.5 \mathrm{mM}+$ Ment

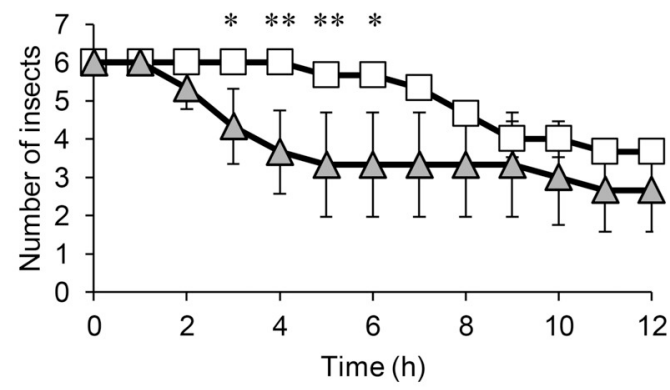

Bend $0.05 \mathrm{mM} \triangle$ Bend $0.05 \mathrm{mM}+$ Ment

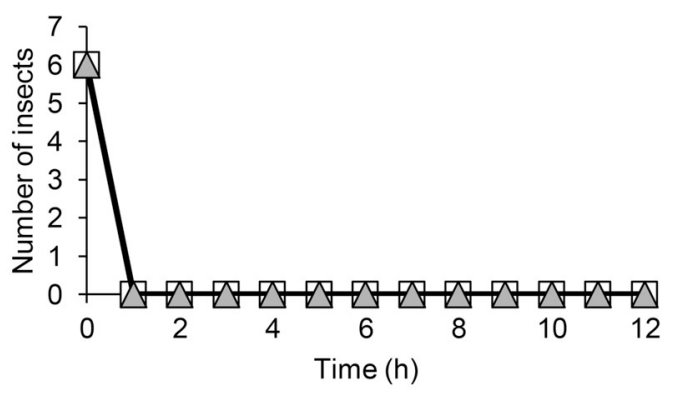

Bend $1 \mathrm{mM}$

\section{Bend $1 \mathrm{mM}+$ Ment}

Fig. 1. Effects of bendiocarb and menthol on in vivo Periplaneta americana - toxicity tests. A). The assessment of motor skills: the insect motor abilities were estimated based on the time required to turn from the dorsal side to the normal position $1 \mathrm{~h}$ after the application of the indicated bendiocarb and menthol combinations. The data is expressed as mean values $\pm \mathrm{SE}, n=15$ and the different letters above the bars refer to statistically significant differences between the data with $p<.05$. B). Knockdown tests-the reduction in the number of the mobile insects over time after the application of the indicated combinations of $0.1 \mu \mathrm{M}$ menthol (Ment) and bendiocarb (Bend). Note the big difference in the menthol enhancing effect for low and high concentrations of bendiocarb. The data is expressed as mean values \pm SE, $n=5$ and the statistically significant differences between bendiocarb and bendiocarb combined with menthol are marked: * $\mathrm{p}<.05,{ }^{* *} p<.01$. C). The dose-effect curves for bendiocarb (continuous line) and bendiocarb co-administered with $0.1 \mu \mathrm{M}$ menthol (dashed line). The effect (normalized) is expressed as a cumulative number of the insects in the knockdown state $12 \mathrm{~h}$ after the administration of chemicals, $n=30$. D). The effective dose values causing 5,10 and $50 \%$ of effect in a knockdown tests. 
different concentrations of bendiocarb alone and in the presence of menthol $(0.1 \mu \mathrm{M})$ were shown in Fig. 1C. The curve plotted for data in the presence of menthol was shifted towards lower bendiocarb concentrations. This change was more pronounced for lower concentrations of bendiocarb. Menthol decreased $\mathrm{ED}^{6}{ }_{5}$ value for bendiocarb 4.5 times and $\mathrm{ED}_{50}$ value 1.7 times (Fig. 1C,D).

\subsection{Influence of menthol on the efficiency of bendiocarb in electrophysiological experiments}

To evaluate the effect of bendiocarb and menthol on the cockroach nervous system, bioelectrical activity of the connective nerve close to the terminal abdominal ganglion was recorded. The magnitude of response to the cercus stimulation and the total activity (meaning the spontaneous activity together with the response to the stimuli) were observed.

\subsubsection{Study of bendiocarb effect on the Periplaneta americana nerve cord}

The examples of the total bioelectric activity of the connective nerve (meaning the responses to the stimulation and the spontaneous activity) were presented on Fig. 2A. In the control conditions, the reactions to the stimulation were well distinguished from the spontaneous activity. When bendiocarb was applied on the preparation the bursts of spontaneous activity were observed. Both parameters: the magnitude of the response to the stimulation and the spontaneous activity were analyzed and compared. In the experiments performed under control conditions, the size of the response slightly decreased at the beginning and usually reached a constant level (about $75 \%$ of initial value) within $15 \mathrm{~min}$ (Fig. 2B). During the experiment, the amount of total activity decreased as well (Fig. 2C).

Bendiocarb was tested at 4 concentrations $(0.1,0.2,0.5,1 \mu \mathrm{M})$ and at these concentrations it did not modify the magnitude of the response to the stimulation (Fig. 2B). However, we observed a new phenomenon where an increase in spontaneous activity appeared in a concentrationdependent manner, often in the form of bursts (Fig. 2A - Bend). When the spontaneous activity was low, the response to the stimulation was well-defined. Conversely, the higher and the irregular spontaneous activity caused by bendiocarb, made it impossible to distinguish the response from the spontaneous firing. In this situation, we decided to analyze the total activity of the preparation - this refers to the spontaneous activity and the response to the stimulation estimated together.

In control conditions, the initial total activity of the connective nerve varied between the preparations and for this reason the data was normalized. The average total activity from the first 40 recordings ( $10 \mathrm{~min}$ ) was set to 1 and from then was referred to as the "basic activity". In all control experiments, the spontaneous activity gradually decreased. After $60 \mathrm{~min}$ of recording only the response to the stimulation was visible and it constituted $14.3 \pm 6.3 \%$ of the basic activity (Fig. 2C).

Bendiocarb in the highest electrophysiologically tested concentration $(1 \mu \mathrm{M})$ induced two kinds of effects. (1) Bendiocarb increased the total activity of the connective nerve (Fig. 2A, C). 30 min after its application, the total activity was 1.8 times higher than in control conditions ( $66.5 \pm 12.7 \%$ of the basic value after bendiocarb application compared to $36.1 \pm 5.7 \%$ in control). $60 \mathrm{~min}$ after application, this activity was recorded as 3.2 times higher $(p<.05)$ than in control $(45.6 \pm 11.4 \%$ vs $14.3 \pm 6.4 \%$, Fig. $2 \mathrm{C})$. The observed increase in the total activity was related only to rise in the spontaneous firing because the size of the response to the stimulation remained almost on the control level (Fig. 2B). (2) Bendiocarb caused frequent, well detectable bursts of activity (Fig. 2A Bend). Such bursts were never observed in the control conditions on the connective nerve and after bendiocarb on the cercal nerve (Supplementary Fig. 1B). The use of bendiocarb in lower

\footnotetext{
${ }^{6} \mathrm{ED}$ - effective dose.
}

concentrations showed its concentration-dependent effect (Fig. 2C). An increase in the total activity was not observed after the application of bendiocarb in the concentration of $0.2 \mu \mathrm{M}$ and lower (Fig. 2C). However, there were exceptions in some cases where the bursts of activity occurred. Calculated $\mathrm{ED}_{50}$ was estimated at $0.5 \mu \mathrm{M}$ (Fig. 4D,E).

\subsubsection{Study of the menthol effect on the Periplaneta americana nerve cord}

Similar to bendiocarb, we began by testing the influence of menthol alone on the response to mechanostimulation. Menthol, in contrast to bendiocarb, changed the response size - Fig. 3A. After its application, the response decreased progressively; the effect was more visible for a lower concentration of the compound. After $30 \mathrm{~min}$ of menthol presence, the size of the response was $47.9 \pm 8.9 \%$ of the basic value at the concentration of $1 \mu \mathrm{M}(p=.0037)$ and only $33.9 \pm 5.5 \%$ at the concentration of $0.1 \mu \mathrm{M}(p=.0009)$. However, in a corresponding time in the control conditions, the response to the stimulation remained stable at the level of $74.2 \pm 5.1 \%$.

To test whether menthol can activate the octopamine receptors, we conducted a series of experiments with a receptor antagonist - phentolamine $(1 \mu \mathrm{M})$, by which the preparation was pretreated. Interestingly, in the presence of phentolamine, $1 \mu \mathrm{M}$ of menthol had no effect on the response to the stimulation and its evolution over time was exactly the same as in the control; after $30 \mathrm{~min}$ it reached $79.7 \pm 5.0 \%$ of the initial value (Fig. 3A). Phentolamine applied separately did not cause any significant effect (Supplementary Fig. 1C).

In additional experiments, we demonstrated a high similarity between the action of menthol and octopamine. When octopamine $(1 \mu \mathrm{M})$ was applied to the nerve cord, it reduced the size of the response to the stimulation recorded from the connective nerve. $30 \mathrm{~min}$ after this, it was at the level of $55.3 \pm 2.0 \%$ of the initial value. In a corresponding time in the control conditions, the response to the stimulation remained stable on the level of $74.2 \pm 5.1 \%$ (difference between octopamine and control in $30 \mathrm{~min}, \mathrm{p}=.0009$ ). A pretreatment of the nerve cord with phentolamine abolished completely the effect of octopamine and the changes in the magnitude of the response over time were similar to the changes in the control conditions (Fig. 3B).

We assumed that menthol and octopamine caused their effects by binding to the same receptor site. To verify this hypothesis, we studied the effect of menthol $(1 \mu \mathrm{M})$ after pretreatment $(10 \mathrm{~min})$ with octopamine $(1 \mu \mathrm{M})$. In $20 \mathrm{~min}$ of applying menthol together with octopamine, the size of the response was equal to $0.48 \pm 0.08$. This value was very similar to the one observed after $30 \mathrm{~min}$ of menthol presence alone at $0.47 \pm 0.07$ (Fig. 3C). This clearly suggests that these molecules bind to the same octopamine receptors.

Menthol $(1 \mu \mathrm{M})$ induced a decrease in the total activity of the connective nerve. Total activity was now up to $15.7 \pm 2.9 \%$ of the basic value compared to $36.1 \pm 5.7 \%$ in the control over $30 \mathrm{~min}$ $(p=.00634)$ and to $4.3 \pm 1.7 \%$ compared to $14.3 \pm 6.4 \%$ within 60 min (Fig. 3D). Quite similar results were obtained with $1 \mu \mathrm{M}$ octopamine (Fig. 3D). When the nerve cord was pretreated with phentolamine, the difference between the control recordings and the recordings after the treatment with menthol was not statistically significant after $30 \mathrm{~min}$. A small, insignificant increase in activity was observed after 60 min, compared to the control (Fig. 3D). The obtained results confirmed our assumption that the effects of menthol are carried out most likely through the octopamine receptors.

\subsubsection{Effect of menthol on the efficiency of bendiocarb}

After $10 \mathrm{~min}$ of the control recordings, the nerve cord was treated with $1 \mu \mathrm{M}$ menthol for $5 \mathrm{~min}$ and then a mixture containing $1 \mu \mathrm{M}$ menthol and $1 \mu \mathrm{M}$ bendiocarb was applied. This did not change the magnitude of the response to the stimulation, just like with bendiocarb alone (Supplementary files, Fig. 1D). As a result, only the total activity of the connective nerve after bendiocarb application was considered in assessing the effect of menthol on bendiocarb efficiency. In $30 \mathrm{~min}$, a slight increase in the total connective nerve activity was observed 
A

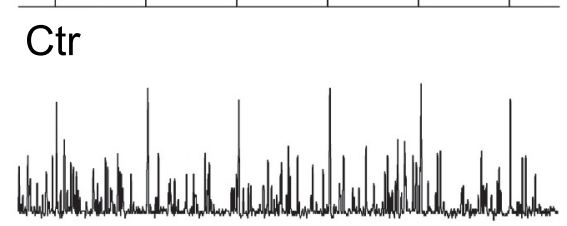

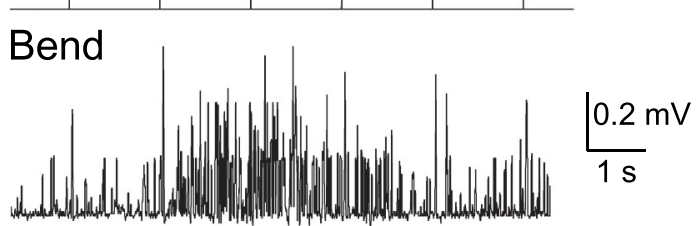
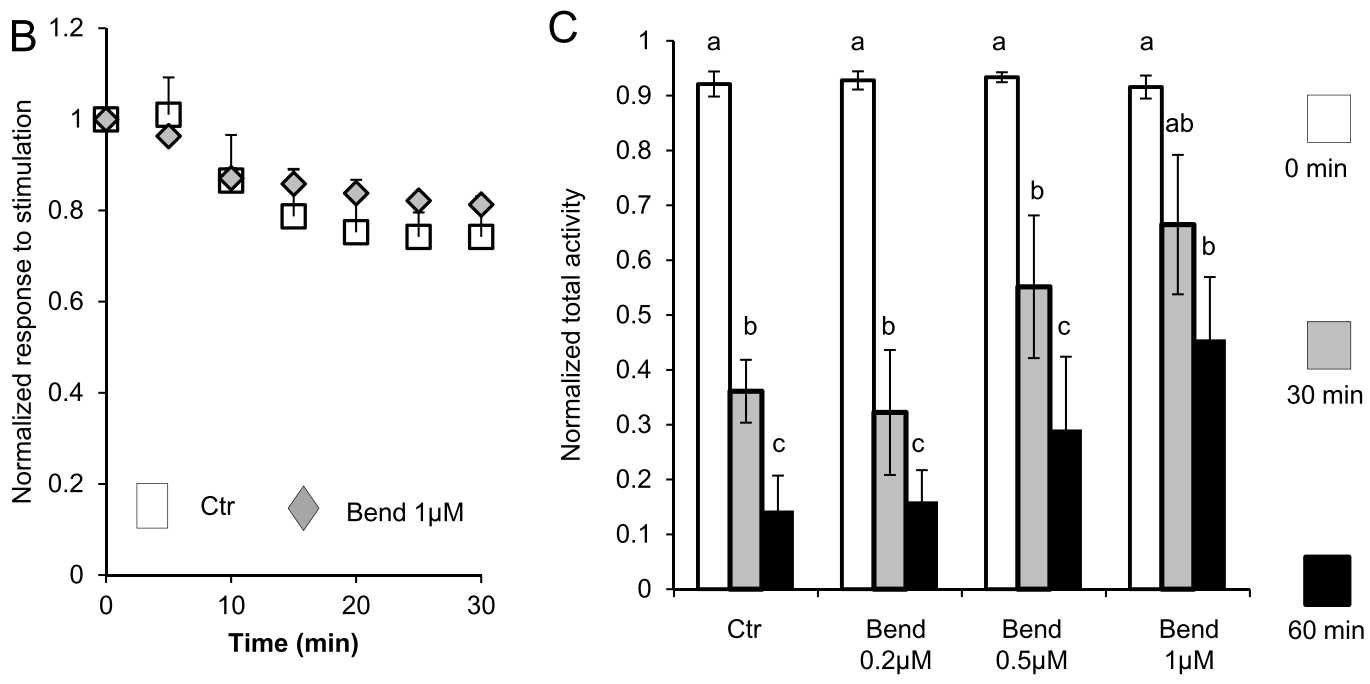

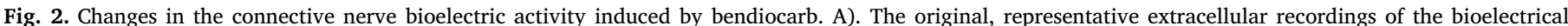

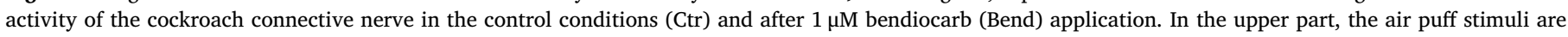

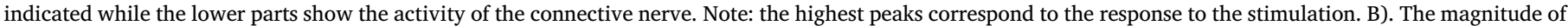

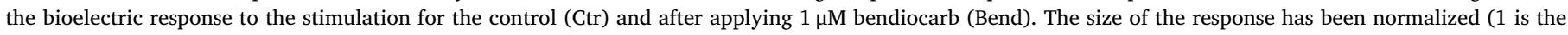

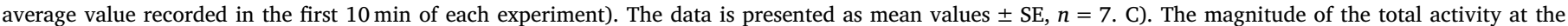

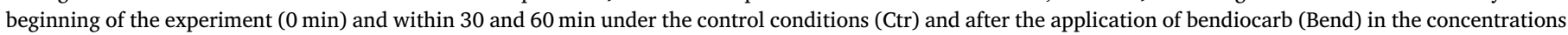

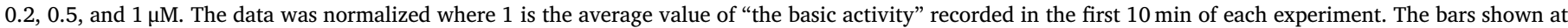

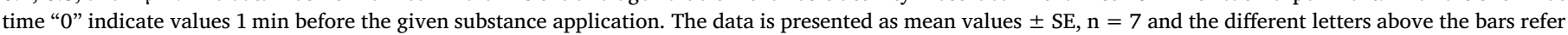
to statistically significant differences between values with $\mathrm{p}<.05$.

compared to the effect of $1 \mu \mathrm{M}$ bendiocarb applied alone (Fig. 4A). Within $60 \mathrm{~min}, 1 \mu \mathrm{M}$ bendiocarb combined with menthol generated a total activity 2.1 times higher $(p=.0021)$ than with bendiocarb applied alone - Fig. 4A. This value was 6.7 times higher $(p=.0015)$ than in the control at a corresponding time of the experiment.

The strengthening effect of menthol was dependent on the concentration of bendiocarb. When the concentration of bendiocarb was higher, in the 60th minute of the experiment the increase in the total nerve activity after the mixture of compounds was bigger compared to the control ( 4 times for $0.2 \mu \mathrm{M}, 5$ times for $0.5 \mu \mathrm{M}$ and 6.7 times for $1 \mu \mathrm{M}$; respectively $p$ values were $0.0015,0.026,0.0015)$. However, the ratio of the activity in the presence of the mixture of the two substances and only bendiocarb was the highest ( 5 times) at the $0.2 \mu \mathrm{M}$ bendiocarb concentration $(p=.019)$ compared to 2.1 times for $1 \mu \mathrm{M}(p=.026)-$ Fig. 4B. This indicates that the potentiation of bendiocarb effect by menthol was largest at the lowest bendiocarb concentration.

Our last goal was to check whether the potentiating effect of menthol on the efficacy of bendiocarb was mediated by the octopamine receptors. For this purpose, we used $1 \mu \mathrm{M}$ phentolamine for $5 \mathrm{~min}$ before testing the effect of the mixture of menthol and bendiocarb on the total activity of the connective nerve. Our assumption was confirmed the evolution of the level of the total activity over time was very similar to that under the control conditions (Fig. 4A). This confirmed unequivocally that menthol potentiates the effect of bendiocarb by activating the octopamine receptors.

In order to visualize the strengthening effect of menthol on the effectiveness of bendiocarb, we present Fig. 4C which convincingly illustrates the development of the potentiating effect of menthol on bendiocarb efficacy in time. On the figure, the high black bars correspond to the bioelectrical discharges with very high frequency. Such phenomena were never observed in the presence of bendiocarb alone.

To better assess the strengthening effect of menthol on bendiocarb activity, the dose-effect curves were calculated and plotted based on the increase in the total activity of the connective nerve in the presence of bendiocarb alone and bendiocarb with $1 \mu \mathrm{M}$ menthol - Fig. 4D. Menthol shifted the dose-effect curve into the lower bendiocarb concentrations. Additionally, it induced the increase in the maximum possible effect of bendiocarb. For better comparison $\mathrm{ED}_{50}, \mathrm{ED}_{10}$ and $\mathrm{ED}_{5}$ were calculated (Fig. 4D,E). $\mathrm{ED}_{50}$ for menthol and bendiocarb together was $0.21 \mu \mathrm{M}$, this means it is over two times lower than for bendiocarb alone $0.50 \mu \mathrm{M}$.

\section{Discussion}

The aim of our research was to check whether menthol - an essential oil component can be used as a substance to strengthen the effect of bendiocarb, a conventional, chemical insecticide. Essential oils have repellent and neurotoxic effects on insects, but their effectiveness is generally lower than that of the classic insecticides (Castillo et al., 2017). Neurotoxicity of essential oils results from the fact that their targets are the key proteins in the insect nervous system: AChE, the GABA and the octopamine receptors (Jankowska et al., 2017; Pavela and Benelli, 2016). One of the strategies to fight against insect pests is to use substances in pairs so that each of them acts on a different target.

Special attention is currently paid to the metabotropic receptor, whose activation may cause strengthening effects (sometimes 
A

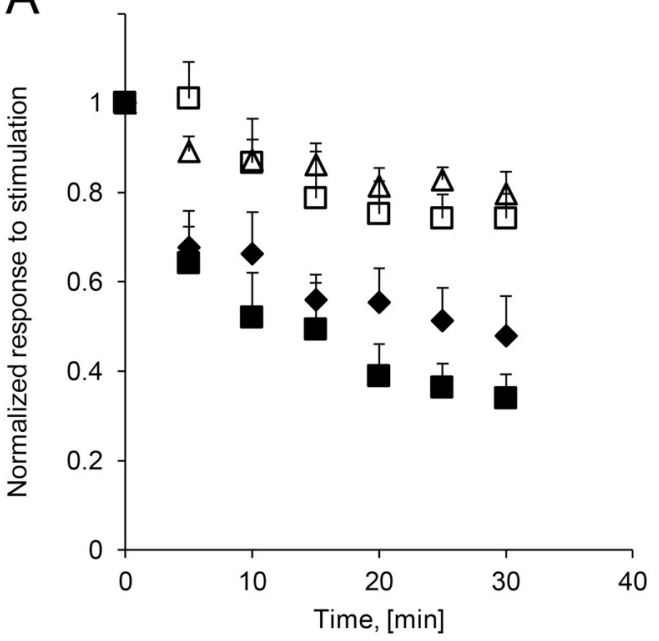

Ctr

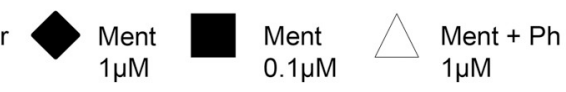

B

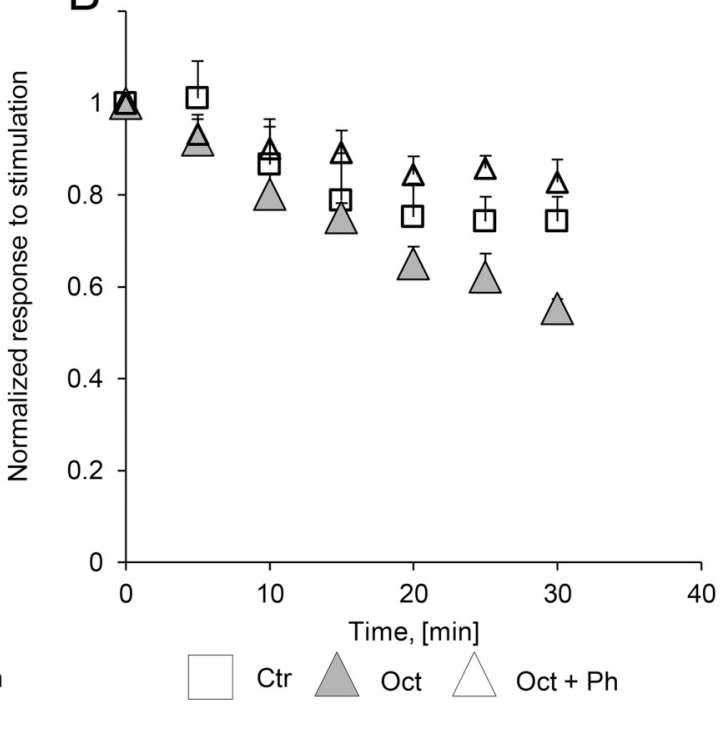

C

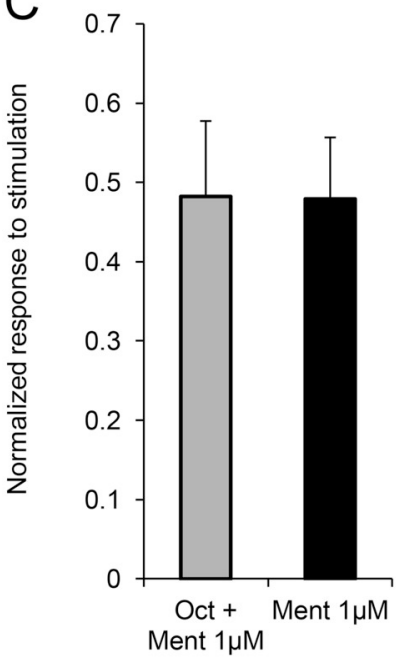

$\mathrm{D}$

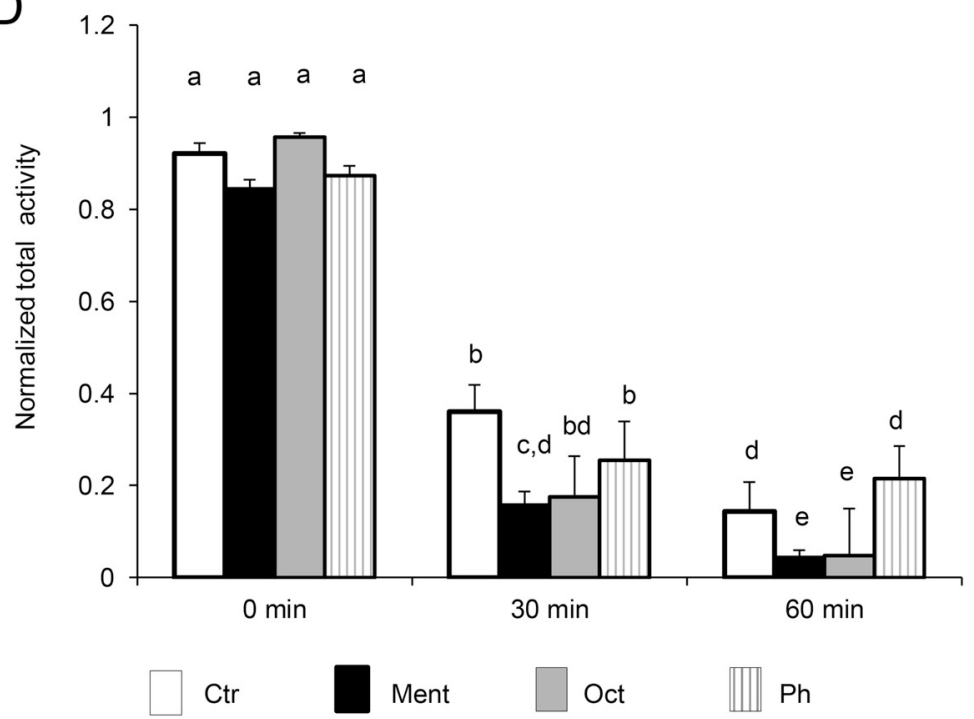

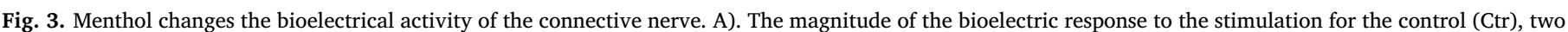

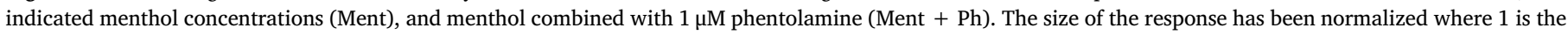

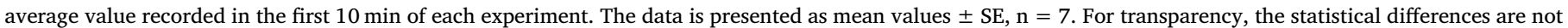

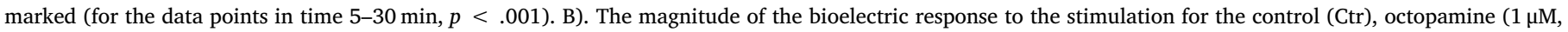

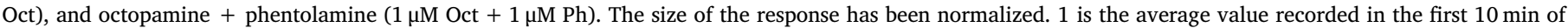

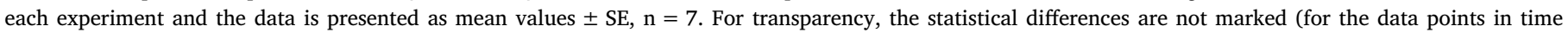

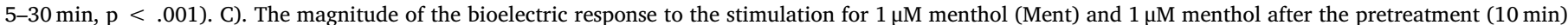

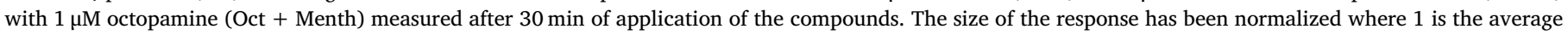

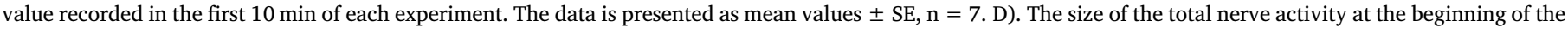

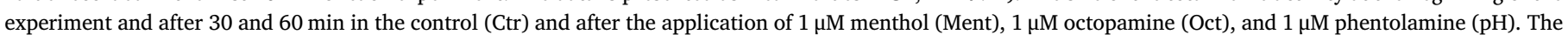

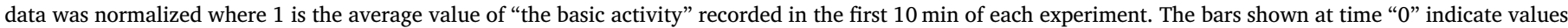

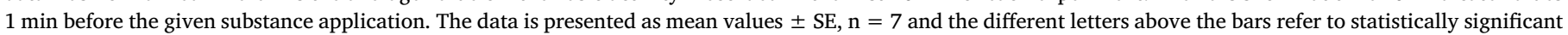
differences between the data with $\mathrm{p}<.05$.

synergistic) with the action of the chemical insecticides (Abd-Ella et al., 2015). We hypothesized that the activation of the octopamine receptors, which trigger the intracellular pathways associated with the increase in cAMP and $\mathrm{Ca}^{2+}$ concentrations, would modify the AChE activity and its sensitivity to chemical inhibitors (carbamates). Achieving a synergistic effect due to the stimulation of the octopamine receptors has already been described (Ahmed and Vogel, 2016). This is particularly valuable because the octopamine receptors play a key regulatory role in insects but occur only in negligible amounts in vertebrates. We assumed that the EO components will "mimic" the effect of octopamine at low concentration, since such an action had already been observed (Glanzman and Krasne, 1983).

In our studies we used menthol, which is considered one of the most active insecticide among the components of EOs (Isman and Machial, 2006). Menthol applied alone showed only insignificant effects in our toxicity tests. Nevertheless it proved to be a strengthening factor for bendiocarb activity. The toxicity tests adequately confirmed our hypothesis that bendiocarb in the presence of menthol is more efficient as an insecticide and this is the main conclusion of our research.

In addition, we wanted to know more about the mechanism of 

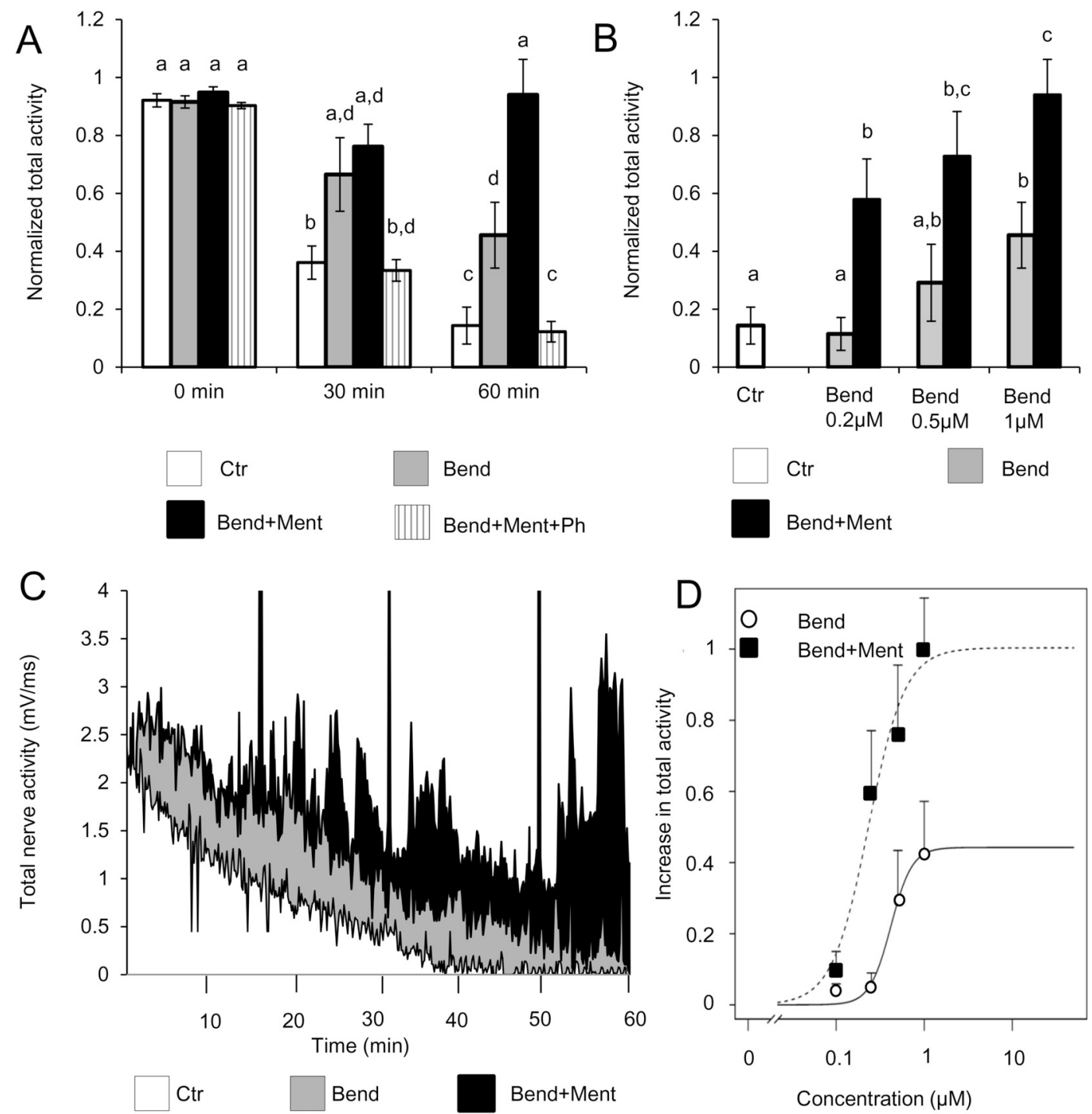

\begin{tabular}{lll} 
E & Bendiocarb & $\begin{array}{l}\text { Bendiocarb }+ \\
\text { Menthol }\end{array}$ \\
\hline $\mathrm{ED}_{5}$ & $0.38 \mu \mathrm{M}$ & $0.049 \mu \mathrm{M}$ \\
$\mathrm{ED}_{10}$ & $0.41 \mu \mathrm{M}$ & $0.071 \mu \mathrm{M}$ \\
$\mathrm{ED}_{50}$ & $0.51 \mu \mathrm{M}$ & $0.21 \mu \mathrm{M}$
\end{tabular}

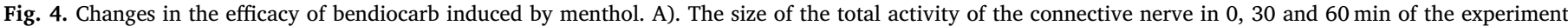

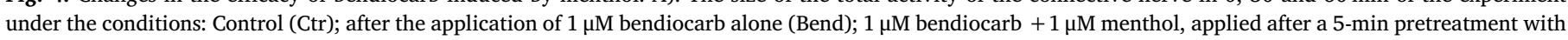

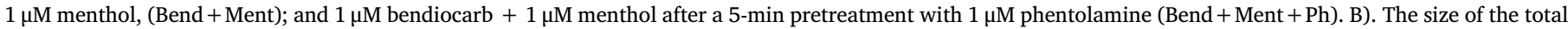

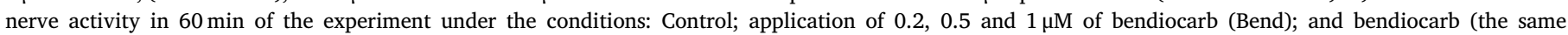

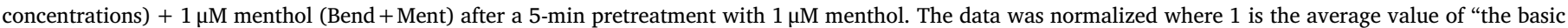

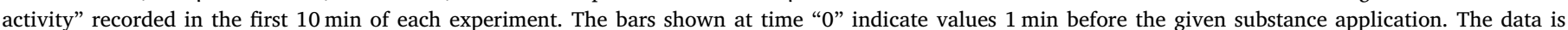

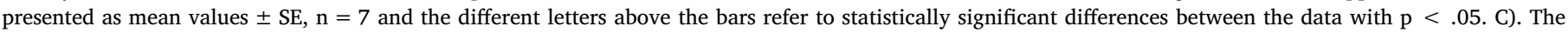

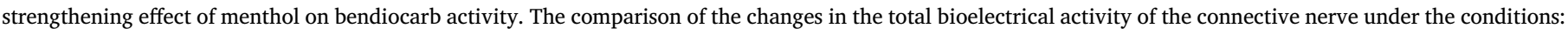

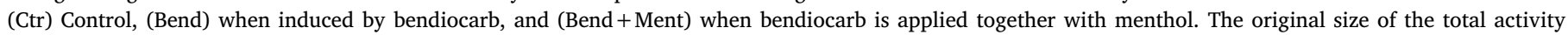

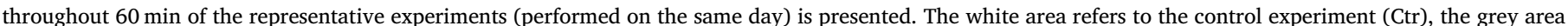

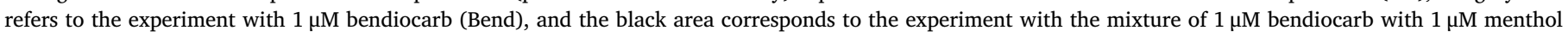

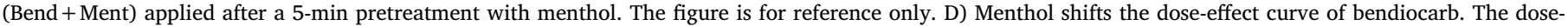

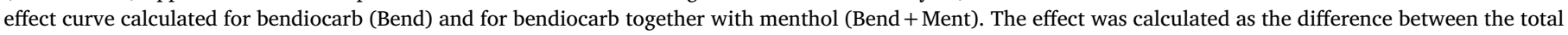

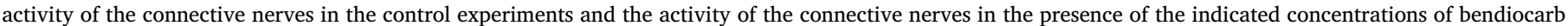

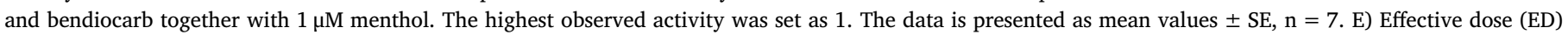

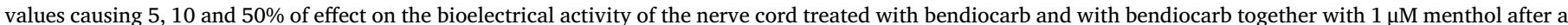

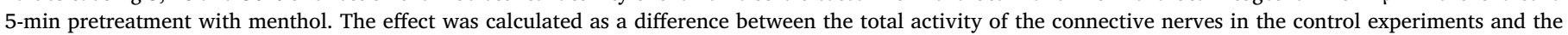
activity of the connective nerves in the presence of the indicated concentrations of bendiocarb and bendiocarb together with $1 \mu \mathrm{M}$ menthol. 
interaction between bendiocarb and menthol at the level of the insect's nervous system. For this purpose, we performed electrophysiological experiments using extracellular recordings of the activity of the cockroach nerve cord.

The observed decrease (by approx. 25\%) in the magnitude of the response to the stimulation under the control conditions resulted from the evolution of the preparation with time. Bendiocarb did not significantly modify the magnitude of the response to the mechanostimulation. This was a surprising phenomenon because the inhibition of AChE should have increased the size of the reaction. However, a release of the $\mathrm{ACh}^{7}$ by the stimulus and its increased levels in a synaptic cleft in the presence of bendiocarb, could have triggered a negative feedback. This could possibly have been through the muscarinic receptors in the presynaptic part that limited the release of ACh in response to the stimulus. Such a phenomenon was observed in this preparation (Corbel et al., 2006). Moreover, in the insect central nervous system ACh binds to different types of nAChR. ${ }^{8}$ These nAChR are composed from homomeric and heteromeric $\alpha 1-8$ subunits as well as non $\alpha$ subunits and are found throughout the whole nervous system of insects. Among them homomeric nAChR (family 1) occurring in the giant fiber of Drosophila melanogaster is known to be crucial for the function of the escape system (Fayyazuddin et al., 2006). Their feature is that they are quickly desensitized with a high amount of ACh (Amar et al., 1995). Therefore, their function is mainly the detection of the stimulus and sending information to the muscles to start the escape. A high level of ACh after an inhibition of AChE may induce a desensitization of these receptors. However, non-desensitizing nAChR can be active and responsible for non-specific excitation of the post-synaptic part, which has been recorded as a high, irregular, bursting connective nerve activity after bendiocarb application. Such over-excitation prevents the detection of the stimuli and induces paralytic effects in the insects. Bendiocarb effects at the level of the insect nervous system corresponded well with the observations obtained in vivo. These were the reasons why mainly the spontaneous activity of nerves was accepted as a parameter to compare the action of bendiocarb alone and in the presence of menthol.

We also assumed that menthol would act as an octopamine receptor agonist so we compared the effects of menthol and octopamine. Octopamine $(1 \mu \mathrm{M})$ caused a decrease in the size of the response to the stimulus compared to the control. A corresponding decrease was also observed in the total activity of the connective nerve. Similarly, octopamine inhibited the excitatory junctional currents in the glutamate neuromuscular junction in Drosophila melanogaster larvae (Nishikawa and Kidokoro, 1999). It also decreased the amplitude of electro-antennogram in Periplaneta americana (Zhukovskaya, 2012). Furthermore, in small concentrations, it decreased the firing rate in heart cells in Drosophila melanogaster (Papaefthimiou and Theophilidis, 2011). Very similar effects in terms of modifying the magnitude of the response to the stimulus and the total nerve activity were obtained after menthol $(1 \mu \mathrm{M})$. The development of the effects with time was similar to that after octopamine.

All kinds of octopamine receptors (Oamb, Octß1R, Octß2R, Octß3R) cover the whole central nervous system of adult insects (ElKholy et al., 2015). They are known to be present in the last abdominal ganglion and in the giant interneurons which make up the connective nerve of Periplaneta americana (Weisel-Eichler and Libersat, 1996). When menthol was applied after octopamine, no additional decrease in the magnitude of response to stimulation was observed. The pretreatment of the preparation with phentolamine - a blocker of the octopamine receptors - abolished completely the effect of octopamine and menthol. All these data strongly suggest that menthol acts through the octopamine receptors.

\footnotetext{
${ }^{7}$ ACh - acetylcholine.

${ }^{8} \mathrm{nAChR}$ - acetylcholine nicotinic receptor.
}

In the toxicity tests and the electrophysiological experiments we observed a surprising phenomenon: (1) cockroaches exposed to the lower concentration of menthol $(0.1 \mu \mathrm{M})$ needed more time to return to the normal position than those exposed to $1 \mu \mathrm{M}$ of menthol and (2) a decrease in the response to the stimuli after exposure to $0.1 \mu \mathrm{M}$ of menthol was larger than after exposure to $1 \mu \mathrm{M}$ of menthol. We suppose that with the higher menthol concentration the desensitization of the receptors could take place. The agonist-induced desensitization of the octopamine receptors has already been described (Orr and Hollingworth, 1990; Robb et al., 1994). Intracellular signaling pathway activated by the binding of menthol to the octopamine receptors can change the phosphorylation state of the receptors and their desensitization. A corresponding desensitization of the octopamine receptor by PKC activation has been described in the nervous system of Drosophila (Hoff et al., 2011).

In the nervous system of the cockroach, it has been found that the increase in the intracellular $\mathrm{Ca}^{2+}$ and the cAMP concentrations modify the affinity of AChE to carbamates (Abd-Ella et al., 2015). Thus, the effect of bendiocarb on AChE in our preparation was expected to change in the presence of menthol. However, the magnitude of the response under the influence of the menthol/bendiocarb mixture was similar to the values recorded under the control conditions. We propose an explanation for this phenomenon similar to that for the case of bendiocarb applied alone and in this situation we evaluated the changes in the total activity of the nerve cord. The effects of bendiocarb in the presence of menthol were more profound than that of bendiocarb only. The efficiency increased almost two fold, when comparing $\mathrm{ED}_{50}$ values (Fig, 4D,E). A very similar potentiation was observed in in-vivo tests. Moreover, the bursting activity was much more expressed, and it developed in time. This corresponded perfectly to the assumption that the strengthening effect of menthol developed during the time needed for the course of the intracellular processes, that end with the phosphorylation of the proteins engaged in the information transmission in the cockroach escape system. A detailed statistical analysis of the effects of bendiocarb alone and in the presence of menthol clearly showed that menthol potentiated the bendiocarb activity. All this interaction was abolished by phentolamine, which confirmed that the potentiation effect occurred through the octopamine receptors.

In our study, we demonstrated a high similarity between the effects of menthol and octopamine (both of which were inhibited by phentolamine). This may suggest that menthol activates octopaminergic receptors. We assumed that activation of octopaminergic receptors would result in higher efficacy of carbamate insecticide (bendiocarb) on insects. Our hypothesis has been confirmed: menthol strongly increases the efficiency of bendiocarb. This positive interaction between menthol and carbamate insecticide has been proven for the first time. The explanation for the mechanisms of this interaction requires further research.

Supplementary data to this article can be found online at https:// doi.org/10.1016/j.pestbp.2019.04.013.

\section{Acknowledgements}

We would like to thank Marta Malewska and Samuel Owusu for stylistic and linguistic improvement of the paper.

\section{Funding}

This work was supported by the National Science Center, Poland [NCN 2014/15/N/NZ9/03868].

\section{References}

Abd-Ella, A., Stankiewicz, M., Mikulska, K., Nowak, W., Pennetier, C., Goulu, M., Fruchart-Gaillard, C., Licznar, P., Apaire-Marchais, V., List, O., Corbel, V., Servent, D., Lapied, B., 2015. The repellent DEET potentiates carbamate effects via insect 
muscarinic receptor interactions: an alternative strategy to control insect vectorborne diseases. PLoS One 10, e0126406. https://doi.org/10.1371/journal.pone. 0126406.

Ahmed, M.A.I., Matsumura, F., 2012. Synergistic actions of formamidine insecticides on the activity of pyrethroids and neonicotinoids against Aedes aegypti (Diptera: Culicidae). J. Med. Entomol. 49, 1405-1410.

Ahmed, M.A.I., Vogel, C.F.A., 2015. Synergistic action of octopamine receptor agonists on the activity of selected novel insecticides for control of dengue vector Aedes aegypti (Diptera: Culicidae) mosquito. Pestic. Biochem. Physiol. 120, 51-56. https://doi.org/ 10.1016/j.pestbp.2015.01.014.

Ahmed, M.A.I., Vogel, C.F.A., 2016. The role of octopamine receptor agonists in the synergistic toxicity of certain insect growth regulators (IGRs) in controlling dengue vector Aedes aegypti (Diptera: Culicidae) mosquito. Acta Trop. 155, 1-5. https://doi. org/10.1016/j.actatropica.2015.11.015.

Amar, M., Thomas, P., Wonnacott, S., Lunt, G.G., 1995. A nicotinic acetylcholine receptor subunit from insect brain forms a non-desensitising homo-oligomeric nicotinic acetylcholine receptor when expressed in Xenopus oocytes. Neurosci. Lett. 199, 107-110.

Antwi, F.B., Reddy, G.V.P., 2015. Toxicological effects of pyrethroids on non-target aquatic insects. Environ. Toxicol. Pharmacol. 40, 915-923. https://doi.org/10.1016/ j.etap. 2015.09.023.

Apaire-Marchais, V., Ogliastro, M., Chandre, F., Pennetier, C., Raymond, V., Lapied, B., 2016. Virus and calcium: an unexpected tandem to optimize insecticide efficacy. Environ. Microbiol. Rep. 8, 168-178. https://doi.org/10.1111/1758-2229.12377.

Beggs, K.T., Tyndall, J.D.A., Mercer, A.R., 2011. Honey bee dopamine and octopamine receptors linked to intracellular calcium signaling have a close phylogenetic and pharmacological relationship. PLoS One 6, e26809. https://doi.org/10.1371/journal. pone.0026809.

Buckingham, S.D., Ihara, M., Sattelle, D.B., Matsuda, K., 2017. Mechanisms of action, resistance and toxicity of insecticides targeting GABA receptors. Curr. Med. Chem. 24, 2935-2945. https://doi.org/10.2174/0929867324666170613075736.

Casida, J.E., Durkin, K.A., 2013. Anticholinesterase insecticide retrospective. Chem. Biol. Interact. 203, 221-225. https://doi.org/10.1016/j.cbi.2012.08.002.

Castillo, R.M., Stashenko, E., Duque, J.E., 2017. Insecticidal and repellent activity of several plant-derived essential oils against Aedes aegypti. J. Am. Mosq. Control Assoc. 33, 25-35. https://doi.org/10.2987/16-6585.1.

Corbel, V., Stankiewicz, M., Bonnet, J., Grolleau, F., Hougard, J.M., Lapied, B., 2006. Synergism between insecticides permethrin and propoxur occurs through activation of presynaptic muscarinic negative feedback of acetylcholine release in the insect central nervous system. Neurotoxicology 27, 508-519. https://doi.org/10.1016/j. neuro.2006.01.011.

Ding, G., Cui, C., Chen, L., Gao, Y., Zhou, Y., Shi, R., Tian, Y., 2015. Prenatal exposure to pyrethroid insecticides and birth outcomes in rural northern China. J. Expo. Sci. Environ. Epidemiol. 25, 264-270. https://doi.org/10.1038/jes.2014.86.

Dong, K., 2007. Insect sodium channels and insecticide resistance. Invertebr. Neurosci. 7, 17-30. https://doi.org/10.1007/s10158-006-0036-9.

El-Kholy, S., Stephano, F., Li, Y., Bhandari, A., Fink, C., Roeder, T., 2015. Expression analysis of octopamine and tyramine receptors in Drosophila. Cell Tissue Res. 361, 669-684. https://doi.org/10.1007/s00441-015-2137-4.

Enan, E., 2001. Insecticidal activity of essential oils: octopaminergic sites of action. Comp. Biochem. Physiol. C. Toxicol. Pharmacol. 130, 325-337.

Enan, E.E., 2005. Molecular and pharmacological analysis of an octopamine receptor from american cockroach and fruit fly in response to plant essential oils. Arch. Insect Biochem. Physiol. 59, 161-171. https://doi.org/10.1002/arch.20076.

Evans, P.D., Maqueira, B., 2005. Insect octopamine receptors: a new classification scheme based on studies of cloned Drosophila G-protein coupled receptors. Invertebr. Neurosci. 5, 111-118. https://doi.org/10.1007/s10158-005-0001-z.

Fayyazuddin, A., Zaheer, M.A., Hiesinger, P.R., Bellen, H.J., 2006. The nicotinic acetylcholine receptor D 7 is required for an escape behavior in Drosophila. PLoS Biol. 4, e63. https://doi.org/10.1371/journal.pbio.0040063.

ffrench-Constant, R.H., Daborn, P.J., Le Goff, G., 2004. The genetics and genomics of insecticide resistance. Trends Genet. 20, 163-170. https://doi.org/10.1016/j.tig. 2004.01.003.

Glanzman, D.L., Krasne, F.B., 1983. Serotonin and octopamine have opposite modulatory effects on the crayfish's lateral giant escape reaction. J. Neurosci. 3, 2263-2269.

Hall, A.C., Turcotte, C.M., Betts, B.A., Yeung, W.Y., Agyeman, A.S., Burk, L.A., 2004 Modulation of human GABAA and glycine receptor currents by menthol and related monoterpenoids. Eur. J. Pharmacol. 506, 9-16. https://doi.org/10.1016/j.ejphar. 2004.10.026.

Hoff, M., Balfanz, S., Ehling, P., Gensch, T., Baumann, A., 2011. A single amino acid residue controls $\mathrm{Ca}^{2+}$ signaling by an octopamine receptor from Drosophila melanogaster. FASEB J. 25, 2484-2491. doi:https://doi.org/10.1096/fj.11-180703.

Ihara, M., Buckingham, S.D., Matsuda, K., Sattelle, D.B., 2017. Modes of action, resistance and toxicity of insecticides targeting nicotinic acetylcholine receptors. Curr. Med. Chem. 24, 2925-2934. https://doi.org/10.2174/0929867324666170206142019.

Isman, M.B., Machial, C.M., 2006. Chapter 2. Pesticides Based on Plant Essential Oils: From Traditional Practice to Commercialization. pp. 29-44. https://doi.org/10. 1016/S1572-557X(06)03002-9.

Jankowska, M., Rogalska, J., Wyszkowska, J., Stankiewicz, M., 2017. Molecular targets for components of essential oils in the insect nervous system-a review. Molecules 23, 34. https://doi.org/10.3390/molecules23010034.

Kostyukovsky, M., Rafaeli, A., Gileadi, C., Demchenko, N., Shaaya, E., 2002. Activation of octopaminergic receptors by essential oil constituents isolated from aromatic plants: possible mode of action against insect pests. Pest Manag. Sci. 58, 1101-1106. https:// doi.org/10.1002/ps.548.

Lapied, B., Pennetier, C., Apaire-Marchais, V., Licznar, P., Corbel, V., 2009. Innovative applications for insect viruses: towards insecticide sensitization. Trends Biotechnol. 27, 190-198. https://doi.org/10.1016/j.tibtech.2008.12.005.

Lavialle-Defaix, C., Moignot, B., Legros, C., Lapied, B., 2010. How does calcium-dependent intracellular regulation of voltage-dependent sodium current increase the sensitivity to the oxadiazine insecticide indoxacarb metabolite decarbomethoxylated JW062 (DCJW) in insect pacemaker neurons? J. Pharmacol. Exp. Ther. 333, 264-272. https://doi.org/10.1124/jpet.109.163519.

Lee, S.E., Lee, B.H., Choi, W.S., Park, B.S., Kim, J.G., Campbell, B.C., 2001. Fumigant toxicity of volatile natural products from Korean spices and medicinal plants towards the rice weevil, Sitophilus oryzae (L). Pest Manag. Sci. 57, 548-553. https://doi.org/ 10.1002/ps.322.

Leyton, V., Goles, N.I., Fuenzalida-Uribe, N., Campusano, J.M., 2014. Octopamine and dopamine differentially modulate the nicotine-induced calcium response in Drosophila mushroom body Kenyon cells. Neurosci. Lett. 560, 16-20. https://doi. org/10.1016/j.neulet.2013.12.006.

Nishikawa, K., Kidokoro, Y., 1999. Halothane presynaptically depresses synaptic transmission in wild-type Drosophila larvae but not in halothane-resistant (har) mutants. Anesthesiology 90, 1691-1697. https://doi.org/10.1097/00000542-19990600000026.

Ogle, D., 2018. Simple Fisheries Stock Assessment Methods. R Package Version 0.8.20. https://cran.r-project.org/web/packages/FSA/index.html, Accessed date: 18 September 2018.

Orr, G.L., Hollingworth, R.M., 1990. Agonist-induced desensitization of an octopamine receptor. Insect Biochem 20, 239-244. https://doi.org/10.1016/0020-1790(90) 90040-2.

Papaefthimiou, C., Theophilidis, G., 2011. Octopamine - a single modulator with double action on the heart of two insect species (Apis mellifera macedonica and Bactrocera oleae): acceleration vs. inhibition. J. Insect Physiol. 57, 316-325. https://doi.org/10. 1016/j.jinsphys.2010.11.022.

Park, C.G., Jang, M., Yoon, K.A., Kim, J., 2016. Insecticidal and acetylcholinesterase inhibitory activities of Lamiaceae plant essential oils and their major components against Drosophila suzukii (Diptera: Drosophilidae). Ind. Crop. Prod. 89, 507-513. https://doi.org/10.1016/J.INDCROP.2016.06.008.

Pavela, R., 2016. History, presence and perspective of using plant extracts as commercial botanical insecticides and farm products for protection against insects - a review. Plant Prot. Sci. 52, 229-241. https://doi.org/10.17221/31/2016-PPS.

Pavela, R., Benelli, G., 2016. Essential oils as ecofriendly biopesticides? Challenges and constraints. Trends Plant Sci. 21, 1000-1007. https://doi.org/10.1016/j.tplants. 2016.10.005.

Perry, T., Batterham, P., Daborn, P.J., 2011. The biology of insecticidal activity and resistance. Insect Biochem. Mol. Biol. 41, 411-422. https://doi.org/10.1016/j.ibmb. 2011.03.003.

Pisa, L.W., Amaral-Rogers, V., Belzunces, L.P., Bonmatin, J.M., Downs, C.A., Goulson, D., Kreutzweiser, D.P., Krupke, C., Liess, M., McField, M., Morrissey, C.A., Noome, D.A., Settele, J., Simon-Delso, N., Stark, J.D., Van der Sluijs, J.P., Van Dyck, H., Wiemers, M., 2015. Effects of neonicotinoids and fipronil on non-target invertebrates. Environ. Sci. Pollut. Res. 22, 68-102. https://doi.org/10.1007/s11356-014-3471-x.

Price, D.N., Berry, M.S., 2006. Comparison of effects of octopamine and insecticidal essential oils on activity in the nerve cord, foregut, and dorsal unpaired median neurons of cockroaches. J. Insect Physiol. 52, 309-319. https://doi.org/10.1016/j.jinsphys. 2005.11.010.

R Development Core Team, 2011. R: A Language and Environment for Statistical Computing [WWW Document].

Raymond, V., Goven, D., Benzidane, Y., List, O., Lapied, B., 2017. Influence of cellular and molecular factors on membrane target sensitivity to insecticides. Curr. Med. Chem. 24, 2974-2987. https://doi.org/10.2174/0929867324666170316111315.

Reale, V., Evans, P.D., Villegas, J., 1986. Octopaminergic modulation of the membrane potential of the Schwann cell of the squid giant nerve fibre. J. Exp. Biol. 121, 421-443.

Ritz, C., Baty, F., Streibig, J.C., Gerhard, D., 2015. Dose-response analysis using R. PLoS One 10, e0146021. https://doi.org/10.1371/journal.pone.0146021.

Robb, S., Cheek, T.R., Hannan, F.L., Hall, L.M., Midgley, J.M., Evans, P.D., 1994. Agonistspecific coupling of a cloned Drosophila octopamine/tyramine receptor to multiple second messenger systems. EMBO J. 13, 1325-1330.

Schinasi, L.H., De Roos, A.J., Ray, R.M., Edlefsen, K.L., Parks, C.G., Howard, B.V., Meliker, J.R., Bonner, M.R., Wallace, R.B., LaCroix, A.Z., 2015. Insecticide exposure and farm history in relation to risk of lymphomas and leukemias in the Women's Health Initiative observational study cohort. Ann. Epidemiol. 25, 803-810. https:// doi.org /10.1016/j.annepidem.2015.08.002.

Tong, F., Coats, J.R., 2010. Effects of monoterpenoid insecticides on $\left[{ }^{3} \mathrm{H}\right]$-TBOB binding in house fly GABA receptor and ${ }^{36} \mathrm{Cl}^{-}$uptake in American cockroach ventral nerve 
cord. Pestic. Biochem. Physiol. 98, 317-324. https://doi.org/10.1016/J.PESTBP. 2010.07.003.

Vehovszky, Á., Szû́cs, A., Szabó, H., Pitt, S., Elliott, C.J.H., 2004. Octopaminergic modulation of the membrane currents in the central feeding system of the pond snail Lymnaea stagnalis. Acta Biol. Hung. 55, 167-176. https://doi.org/10.1556/ABiol.55. 2004.1-4.21.

Vehovszky, A., Szabó, H., Elliott, C.J.H., 2005. Octopamine increases the excitability of neurons in the snail feeding system by modulation of inward sodium current but not outward potassium currents. BMC Neurosci. 6, 70. https://doi.org/10.1186/14712202-6-70

Weisel-Eichler, A., Libersat, F., 1996. Neuromodulation of flight initiation by octopamine in the cockroach Periplaneta americana. J. Comp. Physiol. A. 179, 103-112. https://
doi.org/10.1007/BF00193438.

Wilbrandt, W., 1952. Behrens methods for calculation of LD50. Arzneimittelforschung. 2 $501-503$.

Zeileis, A., 2004. Econometric computing with HC and HAC covariance matrix estimators. J. Stat. Softw. 11. https://doi.org/10.18637/jss.v011.i10.

Zeileis, A., Hothorn, T., 2002. Diagnostic Checking in Regression Relationships. https:// cran.r-project.org/web/packages/lmtest/vignettes/lmtest-intro.pdf, Accessed date: 18 September 2018.

Zhukovskaya, M.I., 2012. Modulation by octopamine of olfactory responses to nonpheromone odorants in the cockroach, Periplaneta americana L. Chem. Senses 37, 421-429. https://doi.org/10.1093/chemse/bjr121. 